\title{
PENGARUH TATA RUANG KANTOR TERHADAP SEMANGAT KERJA PEGAWAI PADA KANTOR PENGAWASAN DAN PELAYANAN BEA DAN CUKAI TIPE PRATAMA PEMATANGSIANTAR
}

\author{
Oleh: \\ Ashari Prabudi \\ S1 Manajemen \\ Parman Tarigan, Liper Siregar, Efendi
}

\begin{abstract}
Abstraksi
Adapun yang menjadi rumusan masalah dalam penelitian ini adalah seberapa besar pengaruh tata ruang kantor terhadap semangat kerja pegawai pada Kantor Pengawasan dan Pelayanan Bea dan Cukai Tipe Pratama Pematangsiantar. Permasalahan ini dijawab dengan mengumpulkan data yang dikumpulkan melalui penelitian kepustakaan dan penelitian lapangan. Data-data yang dikumpulkan berupa data kualitatif dan data kuantitatif. Data-data tersebut bersumber dari sumber data primer dan sekunder. Berhubungan populasi kurang dari 100 yaitu 30 orang, maka sampel yang digunakan seluruh populasi pegawai yang ada pada Kantor Pengawasan Bea dan Cukai Tipe Pratama Pematangsiantar. Adapun data-data tersebut dikumpulkan dengan teknik pengumpulan data melalui kuesioner, wawancara, dan dokumentasi. Untuk teknik analisa yang digunakan adalah teknik analisis deskriptif kualitatif dan analisis deskriptif kuantitatif yang terdiri dari analisis regresi sederhana, analisis koefisien korelasi, analisis koefisien determinasi, dan pengujian hipotesis dengan uji t dengan $\alpha=5 \%$.

Dari hasil analisis regresi sederhana didapatkan $\hat{\mathrm{Y}}=41,68+0,27 \mathrm{X}$, yang artinya ada pengaruh positif antara tata ruang kantor terhadap semangat kerja. Nilai koefisien korelasi didapat $r=0,44$ yang artinya terdapat hubungan baik dan positif antara tata ruang kantor dan semangat kerja. Koefisien determinasi yang didapatkan adalah 19,36\% yang artinya tinggi rendahnya semangat kerja dijelaskan oleh tata ruang kantor sebesar 19,36\% dan sisanya sebesar $80,64 \%$ dipengaruhi faktor lain yang tidak dibahas seperti pemberian kompensasi, intensif, dan motivasi. Dari perhitungan uji $t_{\text {hit }}$ diperoleh 2,59 dan $t_{\text {tab }} 2,048$ di mana $t_{\text {hit }}>t_{\text {tab }}$ yang menunjukkan bahwa $\mathrm{H}_{0}$ ditolak dan menunjukkan adanya pengaruh positif antara tata ruang kantor terhadap semangat kerja. Dari hasil evaluasi diketahui bahwa perlu adanya peningkatan kondisi tata ruang kantor secara kontiniu dengan demikian semangat kerja pegawai tetap baik.
\end{abstract}

Kata kunci: Tata Ruang Kantor dan Semangat Kerja

\section{Abstraction}

As for becoming internal issue formula this research is how big influence of office planology to spirit of job officer at Office of Observation and Service of Toll and Duty of Type of Pratama Pematangsiantar. This Problems is replied by collecting data collected by library research and field research. Data collected in the form of data qualitative and quantitative data. The data stem from source of data of primary and secunder. Correlate the population less than 100 that is 30 people, hence sampel used by entire/all officer population in Office of Observation of Toll and Duty of Type of Pratama Pematangsiantar. As for the data collected with the technique of data collecting questionnaires, interview, and documentation. For the technique of analysis used descriptive analysis technique qualitative and quantitative descriptive analysis consisted of the simple analysis regresi, analyse the correlation coefficient, analyse the coefficient determinasi, and hypothesis examination with the test $t$ by $\alpha=5 \%$..

From result analyse the regresi is modestly got $\hat{\mathrm{Y}}=41,68+0,27 X$, what its meaning there is positive influence between office planology to spirit of job. Assess the correlation coefficient got $r=0,44$ which its meaning there are positive and good relation between office planology and spirit of job. coefficient Determinasi got 19,36\% what its meaning is high lower of spirit of job explained by office planology equal to 19,36\% and the rest of equal to $80,64 \%$ influenced by the other dissimilar factor which is not studied like compensation gift, intensive, and motivate. From calculation test the $t_{\text {hit }}$ obtained 2,59 and $t_{\text {tab }} 2,048$ where about $t_{\text {hit }}>t_{\text {tab }}$ indicating that $H_{0}$ refused and show the existence of positive influence between office planology to spirit of job. From result evaluate known that need existence of condition office planology continually so that the spirit of job officer is good.

Keyword: Office Planology and Spirit of Job 


\section{A. PENDAHULUAN}

\section{Latar Belakang Masalah}

Semangat kerja digunakan untuk menggambarkan suasana keseluruhan yang dirasakan para pegawai dalam kantor. Salah satu faktor yang mempengaruhi semangat kerja adalah tata ruang kantor. Begitu juga dengan Kantor Pengawasan dan Pelayanan Bea dan Cukai Tipe Pratama Pematangsiantar yang ingin memberikan semangat kepada para pegawainya.

Berdasarkan Hasil wawancara pegawai Kantor Pengawasan dan Pelayanan Bea dan Cukai Tipe Pratama Pematangsiantar dapat dilihat bahwa indikator semangat kerja yang belum optimal yaitu pada indikator kerja sama. Belum optimalnya semangat kerja pada indikator kerja sama ini dapat dipengaruhi oleh beberapa faktor, seperti respon terhadap sesama teman kerja pada saat melakukan kegiatan perkantoran. Maka dari itu, semangat kerja bukan saja tergantung pada kondisi pemberian intensif kepada pegawai seperti faktor yang dipengaruhi oleh pemberian gaji saja, melainkan tergantung pada dukungan-dukungan seperti fasilitas yang memuaskan, menempatkan pegawai pada posisi yang tepat, ruangan yang nyaman dan bersih, sistem dan teknis kerja yang serta birokrasi kerja pun sangat mendukung terhadap semangat kerja. Salah satu variabel yang berpengaruh terhadap semangat kerja adalah tata ruang kantor. Tata ruang kantor merupakan salah satu hal penting dalam memasuki sebuah perusahaan. Kantor yang menyenangkan adalah tempat yang tidak membosankan dan dapat menambah semangat kerja dalam rangka mendukung peningkatan mutu kegiatan perkantoran dan tercapainya tujuan perusahaan.

Kondisi tata ruang pada Kantor Pengawasan dan pelayanan Bea dan Cukai Tipe Pratama Pematangsiantar masih ada beberapa ruangan yang kurang teratur dan tidak mencerminkan efek efisiensi dan efektifitas ruang kantor tersebut. Hal ini terlihat pada ruang subseksi perbendaharaan terdapat tumpukan-tumpukan kertas yang berada pada sekitar meja pegawai saat bekerja.

\section{Rumusan Masalah}

a. Bagaimana kondisi tata ruang kantor dan semangat kerja pada Kantor Pengawasan dan Pelayanan Bea dan Cukai Tipe Pratama Pematangsiantar?

b. Seberapa besar pengaruh tata ruang kantor terhadap semangat kerja pada Kantor Pengawasan dan Pelayanan Bea dan Cukai Tipe Pratama Pematangsiantar?

\section{Tujuan Penelitian}

a. Untuk mengetahui kondisi tata ruang kantor kerja dan gambaran semangat kerja pegawai pada Kantor Pengawasan dan Pelayanan Bea dan Cukai Tipe Pratama Pematangsiantar.

b. Untuk mengetahui besarnya pengaruh tata ruang kantor terhadap semangat kerja pegawai pada Kantor Pengawasan dan Pelayanan Bea dan Cukai Tipe Pratama Pematangsiantar.

\section{Metode Penelitian}

Tempat penelitian dalam hal ini adalah Kantor Pengawasan dan Pelayanan Bea dan Cukai Tipe Pratama yang beralamat di Jalan Sisingamangaraja No.66 Pematangsiantar 21147. Adapun populasi pada objek penelitian ini adalah berjumlah 30 orang pegawai, hal ini dikarenakan jumlah populasi terbatas/sedikit maka seluruh populasi dijadikan sampel.

Adapun Desain penelitian yang digunakan dalam penulisan skripsi ini adalah Penelitian Kepustakaan (Library Research) dan Penelitian Lapangan (Field Research). Teknik pengumpulan data yang dilakukan penulis dalam penelitian ini adalah berupa Kuesioner, Wawancara dan Dokumentasi. Adapun jenis data yang digunakan dalam penelitian ini adalah jenis data kualitatif dan data kuantitatif. Hasil data yang diperoleh dari lapangan akan dianalisis secara deskriptif baik bersifat kualitatif dan kuantitatif.

\section{B. LANDASAN TEORI}

\section{Manajemen Sumber Daya Manusia}

Sumber daya manusia memegang peranan yang sangat penting dalam organisasi, karena sumber daya manusia merencanakan, melaksanakan, dan mengendalikan setiap kegiatan organisasi untuk mencapai tujuan. Oleh sebab itu sumber daya manusia harus mendapat perhatian yang lebih serius dibandingkan dengan sumber daya lainnya karena memiliki pikiran, perasaan dan perilaku yang dapat mempengaruhi keberhasilan organisasi. Menurut Rivai (2004:9) manajemen sumber daya manusia merupakan salah satu bidang dari manajemen umum yang meliputi segi-segi perencanaan, pengorganisasian, pelaksanaan, dan pengendalian. Menurut Simamora (2004:4) manajemen sumber daya manusia adalah pendayagunaan, pengembangan, pemberian balas jasa dan pengelolaan individu anggota organisasi atau kelompok karyawan. Dengan demikian penulis menyimpulkan bahwa manajemen sumber daya manusia adalah suatu strategi untuk mendayagunakan orang-orang dalam organisasi atau perusahaan secara efektif dan efisien guna mencapai tujuan organisasi.

\section{Tata Ruang Kantor}

Littlefield dan Peterson dalam Moekijat (2002:118) mendefenisikan tata ruang kantor sebagai penyusunan perkakas dan peralatan dalam ruang lantai tersedia. Penyusunan alat-alat kantor pada letak yang tepat serta pengaturan tempat kerja yang menimbulkan kepuasan bekerja bagi para pegawai di sebut tata ruang perkantoran. Tata ruang ini tidak hanya mengenai penyusunan dan penempatan alat-alat kantor pada tempat yang tepat, akan tetapi tata ruang kantor ini juga mencakup kenyamanan karyawan di dalam menjalankan pekerjaanya. Sedarmayanti (2009:101) tata ruang 
kantor dapat pula diartikan sebagai pengaturan dan penyusunan seluruh mesin kantor, alat perlengkapan kantor serta perabot kantor pada tempat yang tepat, sehingga pegawai dapat bekerja dengan baik, nyaman, leluasa dan bebas bergerak, guna mencapai efisiensi kerja. Dari beberapa pengertian di atas dapat diambil kesimpulan bahwa tata ruang kantor merupakan wadah atau tempat untuk penentuan kebutuhan mengenai ruang dan penggunaanya yang terdiri atas susunan dan letak peralatan serta letak tempat kerja secara nyaman dan efisien yang digunakan untuk menyelesaikan urusan dan tugas tugas perkantoran.

Tata ruang kantor yang baik dapat memberikan manfaat bagi karyawan di dalam menyelesaikan pekerjaanya. Menurut Gie (2000:188) tata ruang kantor mempunyai manfaat sebagai berikut:

a) Mencegah penghamburan tenaga dan para pegawai karena berjalan mondar-mandir yang sebetulnya tidak perlu menjamin kelancaran proses pekerjaan yang bersangkutan.

b) Memungkinkan pemakaian ruang kerja secara efisien, yaitu luas lantai tertentu dapat dipergunakan untuk keperluan yang sebanyak banyaknya.

c) Mencegah para pegawai di bagian lain terganggu oleh publik yang akan menemui suatu bagian tertentu.

d) Pengawasan kerja mudah dilaksanakan.

e) Terciptanya suasana kerja yang menyenangkan.

\section{Semangat Kerja}

Keberhasilan suatu organisasi dipengaruhi oleh semangat kerja pegawai dalam melakukan tugas sesuai dengan tanggung jawab yang diberikan kepadanya. Menurut Hasibuan (2004:94) semangat kerja adalah keinginan dan kesungguhan seseorang mengerjakan pekerjaannya dengan baik serta berdisiplin untuk mencapai produktivitas yang maksimal. Sedangkan menurut Tohardi (2002:427) semangat kerja adalah sikap individu maupun sikap kelompok yang dimiliki oleh para karyawan terhadap lingkungan kerjanya dalam suatu organisasi kerjanya seperti kesetiaan, kerjasama, ketaatan kepada kewajiban dan tugas-tugas organisasi dalam mengejar tujuan bersama. Maka dengan demikian penulis simpulkan bahwa semangat kerja adalah sikap mental seseorang/individu terhadap pekerjaan, dengan memperhatikan keadaan kerja dan kemampuan untuk saling kerjasama dengan giat, disiplin dan rasa tanggung jawab untuk mencapai tujuan dari organisasi atau pun perusahaan.

Semangat kerja karyawan dapat diukur dari beberapa faktor. Menurut Heidjrachman dan Suad (2000:221). Adapun faktor-faktor tersebut adalah sebagai berikut:

a) Disiplin kerja

Disiplin kerja merupakan suatu sikap, tingkah

laku, perbuatan serta pendidikan kesopanan

yang sesuai dengan peraturan-peraturan dari suatu perusahaan baik tertulis maupun tidak tertulis.

b) Absensi

Absensi merupakan tingkat kehadiran maupun tingkat tidak kehadiran dari para karyawan pada suatu perusahaan atau organisasi.

c) Kerjasama

Kerjasama merupakan proses interaksi antar karyawan dalam rangka menyelesaikan pekerjaan dan masalah pekerjaan yang dihadapi.

d) Kepuasan kerja

Kepuasan kerja merupakan tingkat kepuasan karyawan dalam menyelesaikan tugas dan terhadap jaminan-jaminan yang diberikan.

\section{Pengaruh Tata Ruang Kantor Terhadap Semangat Kerja Pegawai}

Demi tercapainya tujuan organisasi, karyawan memerlukan motivasi untuk bekerja lebih rajin. Melihat pentingnya karyawan dalam organisasi, maka karyawan diperlukan perhatian lebih serius terhadap tugas yang dikerjakan sehingga tujuan organisasi tercapai. Dan kondisi tata ruang kantor merupakan salah satu faktor yang dapat meningkatkan semangat kerja pegawai perusahaan.

Menurut Tohardi (2002:427) semangat kerja adalah sikap individu maupun sikap kelompok yang dimiliki oleh para karyawan terhadap lingkungan kerjanya dalam suatu organisasi kerjanya seperti kesetiaan, kerjasama, ketaatan kepada kewajiban dan tugas-tugas organisasi dalam mengejar tujuan bersama. Kantor yang menyenangkan adalah tempat yang tidak membosankan dan dapat menambah semangat kerja pegawai dalam rangka mendukung peningkatan mutu kegiatan perkantoran dan tercapainya tujuan perusahaan, maka secara tidak langsung peranan dan suasana kantor sangat mendukung gairah kerja pegawai yang bekerja dikantor tersebut. Dalam suatu kantor terdapat berbagai sumber daya, dimana sumber daya manusia merupakan faktor utama dari keberadaan suatu kantor dituntut dapat menciptakan kondisi fisik kantor yang baik. Seorang pegawai tidak mungkin dapat bekerja dengan baik jika tidak tersedia tempat kerja yang cukup. Dengan adanya mesin atau tumpukan-tumpukan kertas yang dapat berakibat buruk bagi kesehatan pegawai dan bagi produktifitasnya.

\section{PEMBAHASAN}

\section{Analisa}

\section{a. Deskriptif Kualitatif}

Analisa deskriptif kualitatif dimaksudkan untuk mendapatkan gambaran atau deskripsi mengenai tanggapan dari pegawai mengenai Pengaruh Tata Ruang Kantor Terhadap Semangat Kerja Pada Kantor Bea dan Cukai Tipe Pratama Pematangsiantar. Sesudah pengujian data maka langkah selanjutnya penelitian melakukan pengkajian analisis kualitatif sebagai gambaran fenomenal dari variabel penelitian pada saat sekarang ini.

Adapun penetapan kriteria nilai rata-rata jawaban dari responden tersebut dimasukkan 
kedalam kelas-kelas interval dimana penentuan intervalnya memakai rumus sebagai berikut: Interval Kelas $=$ Nilai Tertinggi - Nilai Terendah

Kriteria:

a. Nilai Tertinggi adalah $=5$

b. Nilai Terendah adalah $=1$

c. Jumlah Kelas adalah $=5$

Dari rumus diatas dapat diperoleh interval kelas 0,8 sehingga berlaku ketentuan kategori dengan hasil sebagai berikut:

Tabel 1

Nilai Interval dan Kategori Jawaban Responden

\begin{tabular}{|c|c|}
\hline Nilai Interval & Kategori \\
\hline $1,00-1,80$ & Sangat Tidak Baik \\
\hline $1,81-2,60$ & Tidak Baik \\
\hline $2,61-3,40$ & Kurang Baik \\
\hline $3,41-4,20$ & Baik \\
\hline $4,21-5,00$ & Sangat Baik \\
\hline
\end{tabular}

Sumber: Hasil Pengolahan Data

\section{1) Gambaran Tata Ruang Kantor pada Kantor Pengawasan dan pelayanan Bea dan Cukai Tipe Pratama Pematangsiantar}

Tata ruang kantor merupakan salah satu hal penting dalam memasuki sebuah perusahaan. Tata ruang kantor yang baik akan membuat seorang pegawai dapat melaksanakan dan meluangkan seluruh tenaga dan pikirannya untuk bekerja secara maksimal. Kantor dengan tata ruang yang tidak teratur pasti membuat tamu kantor berpendapat bahwa kinerja kantor tersebut tersebut tidak jauh berbeda dengan tampilan tata ruangnya.

Kondisi tata ruang kantor dapat memberikan pengaruh terhadap hasil kerja pegawai disuatu perusahaan yang nantinya akan memberikan dampak tersendiri pada perusahaan tersebut. Seperti letak tata ruang yang kurang tepat dan suasana lingkungan perkantoran yang kurang nyaman, atau pun prosedur kerja yang belum sesuai dengan kebutuhan perusahaan itu sendiri, sehingga hal ini dapat membuat karyawan cepat lelah, rasa malas dan suntuk serta kurangnya konsentrasi terhadap pekerjaan, mengulur waktu, pemborosan biaya dalam penggunaan alat tulis kantor (ATK) serta rasa bosan yang terus menerus. Hal ini dapat menjadi suatu permasalahan yang sulit dihindari apabila perusahaan tidak segera mungkin merubah sistem dan menjadikannya lebih baik lagi.

Kondisi tata ruang kantor pada Kantor Pengawasan dan Pelayanan Bea dan Cukai Tipe Pratama Pematangsiantar, sudah bisa dikatakan baik. Namun masih ada juga yang harus diperbaiki dan diperhatikan oleh seorang pimpinan di Kantor Pengawasan dan Pelayanan Bea dan Cukai Tipe Pratama Pematangsiantar, seperti pada ruang perbendaharaan, terlihat kertas-kertas dan berkas berkas kerja yang bertumpukan tidak teratur diantara meja-meja para pegawai, sehingga akan menggangu ruang gerak dan kosentrasi dalam bekerja, maka sebaiknya harus disediakannya lemari khusus tempat penyimpanan kertas-kertas dan berkas-berkas kerja, sehingga akan kelihatan rapi. Selanjutnya arus kerja, proyeksi kebutuhan dimasa datang dan kebutuhan ruang di Kantor Pengawasan dan Pelayanan Bea dan Cukai Tipe Pratama juga terdapat kelemahan dan kurang baik.

Hal ini dikarenakan konsep tata ruang kantor yang diterapkan pada Kantor Pengawasan dan Pelayanan Bea dan Cukai Tipe Pratama Pematangsiantar adalah dengan konsep tata ruang tertutup/berkamar (cubicel type offices), dimana susunan untuk bekerja terbagi-bagi dalam beberapa satuan dan kamar-kamar yang terdiri atas beberapa subseksi-subseksi seperti ruangan subseksi penindakan dan penyelidikan, ruangan subseksi pembendaharaan dan pelayanan, ruangan subseksi kepatuhan dan penyuluhan dan ruangan subseksi urusan umum. Dalam konsep tata ruang kantor tertutup/berkamar mempunyai kerugian apabila menerapkan konsep tata ruang ini.

Pada kolom total jawaban dapat dilihat bahwa sebagian besar responden berpendapat tata ruang kantor pada tahap yang baik. Untuk indikator tugas pegawai pada kategori kondisi perabot kantor di tempat kerja berada pada rata-rata 3,40 yang dinilai kurang baik dan kategori untuk mesin kantor tempat kerja berada pada rata-rata 3,63 yang dinilai baik. Untuk indikator arus kerja pada kategori kondisi arus kerja di ruang kerja pada rata-rata 3,26 yang dinilai kurang baik, hal ini disebabkan karena responden berpendapat jarak antara ruangan yang interaksi saling berkaitan dalam bekerja berjauhan, seperti yang berada pada Kantor Pengawasan dan Pelayanan Bea dan Cukai Tipe Pematangsiantar, ruangan perbendaharaan dan ruangan urusan umum, dimana ruangan perbendaharan berada di lantai satu, sedangkan ruangan urusan umum berada di lantai satu. Sehingga untuk kategori jarak antara teman kerja berada pada rata-rata 3,30 yang dinilai kurang baik.

Untuk indikator bagan organisasi pada kategori identifikasi hubungan kerja berada pada rata-rata 3,36 yang dinilai kurang baik, pada kategori kondisi identitas tata ruang kantor berada pada ratarata 3,46 yang dinilai baik. Selanjutnya untuk indikator proyeksi kebutuhan kerja di masa datang pada kategori perubahan tata ruang jika terdapat penambahan perabot berada pada rata-rata 3,50 yang dinilai baik dan pada perubahan tata ruang kantor jika terdapat penambahan pegawai berada pada ratarata 3,33 yang dinilai kurang baik, hal ini menurut responden disebabkan karena jenis tata ruang kantor yang dipakai pada Kantor Pengawasan dan Pelayanan Bea dan Cukai Tipe Pratama Pematangsiantar dengan konsep tata ruang terpisahpisah, dimana susunan untuk bekerja terbagi-bagi dalam beberapa kamar-kamar, sehingga harus menunggu beberapa waktu terlebih dahulu.

Pada indikator jaringan komunikasi pada kategori volume interaksi antara sesama pegawai berada pada rata-rata 3,46 yang dinilai baik, sedangkan interaksi antara pimpinan dan bawahan berada rata-rata 3,36 yang dinilai kurang baik. Hal 
ini menurut responden disebabkan sering para pegawai melakukan tugas luar kota, seperti melakukan monitoring perusahaan-perusahaan yang terkait perdagangan ekspor dan impor, sehingga interaksi komunikasi antar pimpinan dan bawahan jarang bertemu. Untuk indikator departemen dalam organisasi pada kategori ruang kerja telah sesuai dengan penempatan pegawai berada pada rata-rata 3,36 yang dinilai kurang baik, pada kategori situasi tempat kerja dalam meningkatkan kosentrasi kerja pegawai berada pada rata-rata 3,53 yang dinilai baik. Selanjutnya pada indikator kebutuhan ruang pada kategori kondisi tata ruang telah sesuai dengan luas ruangan berada pada rata-rata 3,56 yang dinilai baik, sehingga ruang gerak antara pegawai berjalan lancar. Pada kategori luas ruangan telah sesuai dengan jumlah berada pada rata-rata 3,36 yang dinilai kurang baik, hal ini menurut responden disebabkan setiap tahunnya bertambah beberapa penempatan pegawai baru, yang sudah menyelesaikan pendidikan di Sekolah Tinggi Akuntansi Negara (STAN).

Untuk indikator pertimbangan keamanan pada kategori lingkungan kerja terhadap keamanan berada pada rata-rata 3,56 yang dinilai baik, sedangkan kondisi lingkungan kerja terhadap kenyamanan pegawai juga berada pada rata-rata 3,43 yang dinilai baik, karena keamanan dan kenyamanan ruang kerja dapat menentukan hasil dalam bekerja, untuk itu kenyamanan juga dapat memberikan semangat kerja pegawai tersebut. Selanjutnya pada indikator pembiayaan ruang kantor pada kategori kebersihan ruang kerja berada pada rata-rata 3,83 yang dinilai baik, karena kebersihan ruang kerja sangat menentukan kenyamanan dalam bekerja, selain itu kebersihan juga merupakan sebagian dari iman, sedangkan kategori pemeliharaan tata ruang berada pada rata-rata 3,43 yang dinilai baik.

Dari total jawaban responden mengenai tata ruang kantor terdapat hasil yaitu: berada pada ratarata 3,45 dengan kriteria jawaban baik membuktikan bahwa para responden menganggap kondisi tata ruang kantor dan suasana kerja pada Kantor Pengawasan dan Pelayanan Bea dan Cukai Tipe Pratama Pematangsiantar sudah berada pada kondisi baik.

\section{2) Semangat Kerja Pegawai pada Kantor Pengawasan dan Pelayanan Bea dan Cukai Tipe Pratama Peamatangsiantar}

Semangat kerja pada dasarnya merupakan suatu kondisi rohaniah dan perilaku dari individu pegawai dan kelompok-kelompok yang menimbulkan kesenangan yang mendalam pada diri pegawai untuk bekerja dengan giat dan konsekuen dalam mencapai tujuan-tujuan yang telah ditetapkan oleh organisasi tersebut. Selanjutnya bahwa dari penjelasan pada bab II dapat kita ambil beberapa hal penting seperti, apabila pimpinan mampu meningkatkan semangat kerja pegawainya maka akan dapat diperoleh banyak keuntungan, pekerjaan akan lebih cepat diselesaikan, kerusakan akan dapat dikurangi, absensi akan dapat diperkecil. Maka dari itu Kantor Pengawasan dan Pelayanan Bea dan Cukai Tipe Pratama Pematangsiantar, hendaknya memperlakukan pegawai secara layak dan adil sehingga mereka dapat melaksanakan tugas dengan sungguh-sungguh dan penuh tanggung jawab.

Pada kolom total jawaban dapat dilihat bahwa sebagian besar responden menjawab tinggi, baik itu dari indikator kesetiaan, kerja sama, ketaatan pada kewajiban dan melaksanakan tugas organisasi. Dari tabel diatas juga, dapat diketahui bahwa pada indikator kesetiaan pada kategori rasa peduli pegawai terhadap kemajuan perusahaan berada pada rata-rata 4,13 yang dinilai baik, selanjutnya rasa setia kepada perusahaan berada pada rata-rata 4,13 yang dinilai baik, begitu juga pada kategori usaha dalam kemajuan perusahaan berada pada rata-rata 4,07 yang dinilai baik. Untuk indikator kerja sama pada kategori kerjasama satu sama lain dalam bekerja berada pada rata-rata 4,23 yang dinilai sangat baik. Pada kategori membantu antara teman bekerja berada pada rata-rata 4,27 yang dinilai sangat baik. Pada kategori respon membantu anda pada teman sejawat berada pada rata-rata 4,06 yang dinilai baik. Hubungan antara pimpinan dan bawahan berada pada rata-rata 4,23 yang dinilai sangat baik. Sedangkan rasa peduli terhadap teman yang sedang kesulitan berada pada rata-rata 4,37 yang dinilai sangat baik.

Selanjutnya untuk indikator ketaatan pada kewajiban pada kategori penyelesaian pekerjaan berada pada rata-rata 4,23 yang dinilai sangat baik. Selanjutnya pada kategori dedikasi terhadap perusahaan berada pada rata-rata 4,20 yang dinilai baik. Dengan adanya dedikasi yang tinggi maka loyalitas terhadap perusahaan tersebut juga baik. Sedangkan pada kategori kepatuhan kepada peraturan berada pada rata-rata 4,10 yang dinilai baik. Untuk indikator melaksanakan tugas organisasi pada kategori cara penyelesaian tugas berada pada rata-rata 4,17 yang dinilai baik, pada kategori tanggung jawab berada pada rata-rata 4,07 yang dinilai baik, sedangkan pada kategori target yang diberikan perusahaan berada pada rata-rata 4,20 yang dinilai baik.

Untuk total jawaban responden mengenai semangat kerja pegawai baik dari segi faktor kesetiaan, faktor kerjasama, faktor ketaatan pada kewajiban dan faktor melaksanakan tugas organisasi mendapat nilai rata-rata sebesar 4,17 dengan kriteria jawaban baik. Oleh karena itu dapat diambil kesimpulan bahwa para pegawai memiliki semangat kerja yang sangat tinggi, dengan apa yang memang diharapkan Kantor Pengawasan dan Pelayanan Bea dan Cukai Tipe Pratama Pematangsiantar.

\section{b. Deskriptif Kuantitatif}

\section{1) Analisa Regresi Linear Sederhana}

Penelitian ini memiliki tujuan untuk menganalisis pengaruh Tata ruang kantor terhadap semangat kerja. Analisis data dalam penelitian ini menggunakan analisis regresi sederhana. Analisis regresi linier sederhana digunakan untuk mengetahui 
pengaruh variable bebas $(\mathrm{X})$ dan variable terikat $(\mathrm{Y})$, dimana $\mathrm{X}$ adalah Tata ruang kantor, dan $\mathrm{Y}$ adalah semangat kerja pegawai. Analisis dilakukan dengan melakukan tabulasi jawaban responden pada kuesioner yang telah dijalankan.

Untuk melihat pengaruh variable dengan persamaan regresi tersebut, maka dilakukan perhitungan secara manual untuk memperoleh nilai a dan b, dengan notasi sebagai berikut: $\hat{\boldsymbol{Y}}=\mathbf{a}+\mathbf{b X}$

$\hat{\gamma}=$ Variabel Terikat (Semangat Kerja)

$\mathrm{X}=$ Variabel Bebas (Tata Kuang Kantor)

$\mathrm{a}=$ Intersep

$\mathrm{b}=$ Koefisien Regresi

Untuk nilai $b$ :

$b=\frac{\mathrm{n}(\Sigma \mathrm{XY})-(\Sigma \mathrm{X})\left(\sum \mathrm{Y}\right)}{\mathrm{n}\left(\Sigma \mathrm{X}^{2}\right)-\left(\sum \mathrm{X}\right)^{2}}$

$b=\frac{30(109083)-(1865)(1754)}{30(11099)-(1965)^{2}}$

$b=\frac{3272490-3271210}{3482970-3478225}$

$b=\frac{1280}{4745}$

$b=\mathbf{0 , 2 7}$

Sedangkan untuk nilai a:

$\mathrm{a}=\frac{\sum \mathrm{Y}-\mathrm{b} \Sigma \mathrm{X}}{\mathrm{D}}$

$\mathrm{a}=\frac{1754-0.27(1865)}{30}$

$\mathrm{a}=\frac{1754-503,55}{30}$

$\mathrm{a}=\frac{1250,45}{30}$

$\mathrm{a}=\mathbf{4 1 , 6 8}$

Berdasarkan hasil pengolahan data didapat persamaan regresi linier sederhana sebagai berikut: $\hat{Y}=\mathbf{4 1 , 6 8}+\mathbf{0 , 2 7 X}$ yang bertanda positif, artinya terdapat pengaruh yang positif antara variabel bebas (tata ruang kantor) dan variable terikat (semangat kerja pegawai) pada Kantor Pengawasan dan Pelayanan Bea dan Cukai Tipe Pratama Pematangsiantar. Dimana kondisi tata ruang kantor yang efektif dan efesien dapat memberikan semangat kerja bagi para pegawai.

\section{2) Analisa Korelasi dan Determinasi}

Analisis distribusi frekuensi jawaban responden menurut skor dari variabel $\mathrm{X}$ dan $\mathrm{Y}$ dimaksud sebagaimana yang telah dilakukan, hanyalah bermanfaat untuk memberikan informasi pendahuluan mengenai pola distribusi jawaban responden menurut skor. Selanjutnya dilakukan perhitungan korelasi berupa derajat atau kedalaman hubungan fungsional yang menjelaskan hubungan antar perubah, dinyatakan dengan yang dinamakan koefisien korelasi yang sering disimbolkan dengan $r$, nilai $r$ dapat dihitung sebagai berikut:

$$
\begin{aligned}
& r=\frac{n \sum X Y-\sum X \sum Y}{\sqrt{n \sum X^{2}-\left(\sum X\right)^{2} \sqrt{n \sum Y^{2}-\left(\sum Y\right)^{2}}}} \\
& r=\frac{30(109083)-(1865)(1754)}{\sqrt{30(116099)-(1865)^{2} \sqrt{30(102610)-(1754)^{2}}}} \\
& r=\frac{3272490-3271210}{\sqrt{3487050-3478225} \sqrt{3301380-3297856}} \\
& r=\frac{\frac{2320}{\sqrt{4745} \sqrt{1784}}}{}
\end{aligned}
$$

$$
\begin{aligned}
& r=\frac{2320}{(68,88)(42,23)} \\
& r=\mathbf{0 , 4 4}
\end{aligned}
$$

Dari hasil perhitungan diatas diperoleh nilai $r$ $=0,44$ artinya terdapat hubungan dalam kategori sedang antara variabel $\mathrm{X}$ yaitu variabel tata ruang kantor dan variabel $\mathrm{Y}$ yaitu semangat kerja pegawai. Hal ini disebabkan karena pada sebagian besar pegawai berpendapat bahwa tata ruang kantor tidak terlalu mempengaruhi semangat kerja mereka. Para pegawai berpendapat bahwa berhasil tidaknya karir mereka tergantung pada diri dan hasil kerja mereka masing-masing.

Selanjutnya untuk mengukur seberapa besar variabel bebas menjelaskan variabel terikat maka digunakan koefisien determinasi (R). Nilai (R) dapat diperoleh dari:

$\mathrm{R}=r^{2} \times 100 \%$

$\mathrm{R}=0.44^{2} \times 100 \%$

$\mathrm{R}=0,1936 \times 100 \%$

$\mathrm{R}=19,36 \%$

Dari perhitungan koefisien determinasi diatas menunjukkan bahwa tinggi rendahnya semangat kerja 19,36\% dapat dijelaskan oleh tata ruang kantor pada Kantor Pengawasan dan Pelayanan Bea dan Cukai Tipe Pratama Pematangsiantar, dan sisanya $80,64 \%$ dapat dijelaskan oleh faktor lain yang tidak dibahas dalam penelitian ini, seperti kompensasi, intensif, motivasi, kepemimpinan, dan faktor lainnya. Seperti penjelasan dari hasil koefisien korelasi diatas, pada koefisien determinasi yang mendapat hasil perhitungan hanya sebesar 19,36\%, juga disebabkan karena tata ruang kantor tidak menjadi hal penting dalam memberikan semangat kerja bagi para pegawai.

Bagi para pegawai yang menjadi responden dalam pengisian kuesioner berpendapat semangat kerja mereka lebih dipengaruhi oleh tingkat kesejahteraan, hubungan yang baik dengan pimpinan, rekan kerja serta fasilitas-fasilitas yang diberikan perusahaan. Sedangkan faktor lain sebesar $80,64 \%$ lebih mempengaruhi dalam menciptakan semangat kerja seperti: kompensasi, itensif, motivasi, kepemimpinan, dll.

\section{3) Uji Hipotesis}

Uji $\mathrm{t}$ digunakan untuk menguji pengaruh variabel bebas terhadap variabel terikat secara parsial atau individual. Untuk menguji hasil perhitungan regresi dapat dapat dilakukan dengan pembuktian hipotesa untuk mengetahui apakah variabel bebas mempunyai pengaruh atau tidak terhadap variabel terikat secara parsial.

$$
\begin{aligned}
& t_{\text {hit }}=\frac{r \sqrt{n-2}}{\sqrt{1-r^{2}}} \\
& t_{h i t}=\frac{0.44 \sqrt{30-2}}{\sqrt{1-(0.44)^{2}}} \\
& t_{\text {hit }}=\frac{0.44 \sqrt{28}}{\sqrt{1-(0,1936)}} \\
& t_{\text {hit }}=\frac{0.44(5.9)}{\sqrt{0.8064}}
\end{aligned}
$$


$t_{\text {hit }}=\frac{z, 832}{0.8979}$

$t_{\text {hit }}=2.59$

Dari hasil pengujian $t_{\text {hit }}$ sebesar 2,59 sedangkan ttab pada tingkat kepercayaan $95 \%$ adalah sebesar 2,048. oleh karena $t_{\text {hit }}>$ ttab, berarti variabel tata ruang kantor berpengaruh positif terhadap semangat kerja pegawai, sehingga Ho ditolak dan Ha diterima, artinya kondisi tata ruang kantor berpengaruh positif terhadap semangat kerja pegawai pada Kantor Pengawasan dan Pelayanan Bea dan Cukai Tipe Pratama Pematangsiantar.

\section{Evaluasi}

a. Tata Ruang Kantor pada Kantor Pengawasan dan Pelayanan Bea dan Cukai Tipe Pratama Pematangsiantar

Tata ruang kantor merupakan salah satu hal penting dalam memasuki sebuah perusahaan. Kantor yang menyenangkan adalah tempat yang tidak membosankan dan dapat menambah semangat kerja pegawai dalam rangka mendukung peningkatan mutu kegiatan perkantoran dan tercapainya tujuan perusahaan, maka secara tidak langsung peranan dan suasana kantor sangat mendukung gairah pegawai yang bekerja di kantor tersebut. Oleh sebab itu maka diperlukan adanya suatu pemikiran untuk dapat menciptakan kantor dengan suasana yang nyaman, teratur, aman dengan fasilitas yang memang diperlukan oleh kegiatan kantor tersebut. Akan tetapi untuk indikator tugas pegawai pada kategori perabot kantor, mendapatkan respon yang kurang baik, hal ini dapat dibuktikan dari nilai rata-rata 3,40 kurang baik. Untuk indikator arus kerja pada kategori kondisi arus kerja, mendapatkan respon yang kurang baik, hal ini dapat dibuktikan dari nilai rata-rata 3,26 dengn kriteria kurang baik, seperti hal nya juga dengan kategori, jarak ruangan dan identifikasi hubungan kerja, mendapatkan respon yang kurang baik pula, hal ini dapat dibuktikan dari nilai rata-rata, untuk jarak ruang mendapatkan nilai rata-rata 3,30, pada idenfikasi hubungan kerja mendapatkan nilai ratarata 3,36 dengan kriteria kurang baik untuk kedua kategori tersebut.

Selanjutnya pada indikator proyeksi kebutuhan kerja dimasa datang pada kategori perubahan tata ruang jika terdapat penambahan pegawai, mendapatkan respon yang kurang baik, hal ini dapat dibuktikan dari nilai rata-rata responden sebesar 3,33 dengan kriteria jawaban kurang baik. Selanjutnya indikator jaringan komunikasi pada kategori interaksi anatar pimpinan dan bawahan, mendapatkan respon yang kurang baik juga, hal ini dapat dibuktikan dari nilai rata-rata responden 3,36 dengan kriteria jawaban kurang baik. Begitu juga pada indikator departemen dalam organisasi, pada kategori kondisi ruang kerja telah sesuai dengan penempatan pegawai, mendapatkan respon yang kurang baik juga, hal ini dapat dibuktikan dari nilai rata-rata responden sebesar 3,36 dengan kriteria jawaban kurang baik.
Untuk indikator kebutuhan ruang pada kategori luas ruangan telah sesuai dengan jumlah pegawai, mendapatkan respon yang kurang baik juga, hal ini dapat dibuktikan dari nilai rata-rata responden sebesar 3,36 dengan kriteria jawaban kurang baik. Maka sudah seharusnya pimpinan Kantor Pengawasan dan Pelayanan Bea dan Cukai Tipe Pratama Pematangsiantar harus selalu melaksanakan pelaksanaan tata ruang kantor yang memperhatikan efek efektivitas bukan hanya efek efisiensinya saja, karena efisiensi tata ruang kantor belum tentu bisa membuat efektif suatu ruangan, jadi apabila penataan tata ruang kantor dilakukan secara baik maka akan berpengaruh terhadap semangat kerja pegawai tersebut.

\section{b. Semangat Kerja Pegawai pada Kantor Pengawasan dan Pelayanan Bea dan Cukai Tipe Pratama Pematangsiantar}

Kantor yang menyenangkan adalah tempat yang tidak membosankan dan dapat menambah semangat kerja pegawai dalam rangka mendukung peningkatan mutu kegiatan perkantoran dan tercapainya tujuan perusahaan, maka secara tidak langsung peranan dan suasana kantor sangat mendukung gairah pegawai yang bekerja di kantor tersebut. Oleh sebab itu maka diperlukan adanya suatu pemikiran untuk dapat menciptakan kantor dengan suasana yang nyaman, teratur, aman dengan fasilitas yang memang diperlukan oleh kegiatan kantor tersebut. Dalam hal semangat kerja yang menjadi indikator dalam kuesioner yang disebarkan kepada responden adalah tentang faktor kesetiaan, faktor kerjasama, faktor, ketaatan pada kewajiban dan melaksanakan tugas organisasi.

Dimana dari beberapa faktor tersebut hasil yang didapat menyatakan semangat kerja di Kantor Pengawasan dan Pelayanan Bea dan Cukai Tipe Pratama Pematangsiantar baik, hal ini dapat dilihat dari tabel 9, dimana rata-rata 4,17 dengan kriteria baik semangat kerja pada Kantor Pengawasan dan Pelayanan Bea dan Cukai Tipe Pratama Pematangsiantar. Untuk mengetahui seberapa besar tata ruang kantor menjelaskan semangat kerja dapat dilihat dari hasil koefisien determinasi. Pada perhitungan koefisien determinasi mendapat hasil sebesar 19,36\%, hal ini disebabkan karena tata ruang kantor tidak menjadi hal penting dalam memberikan semangat kerja para pegawai.

Bagi para pegawai yang menjadi responden dalam pengisian kuesioner berpendapat semangat kerja mereka lebih dipengaruhi oleh tingkat kesejahteraan, hubungan yang baik dengan pimpinan, rekan kerja serta fasilitas-fasilitas yang diberikan perusahaan. Dan sisanya sebesar $80,64 \%$ dijelaskan oleh faktor lain yang tidak dibahas dalam penelitian ini seperti kompensasi, insentif, kepemimpinan dan lainnya.

\section{KESIMPULAN DAN SARAN}

\section{Kesimpulan}

a. Dari hasil kuesioner tentang Tata ruang kantor memiliki nilai rata-rata sebesar 3,45 dengan 
kriteria baik. Namun masih ada kelemahan untuk indikator arus kerja pada kategori kondisi arus kerja yang memiliki nilai rata-rata 3,26 dengan kriteria kurang baik.

b. Dari hasil pengolahan kuesioner tentang semangat kerja pegawai memiliki nilai rata-rata sebesar 4,17 dengan kriteria baik. Namun masih ada kelemahan pada indikator kerja sama pada kategori respon terhadap sesama teman kerja masih dibawah nilai rata-rata.

c. Dari perhitungan persamaan regresi sederhana yang dilakukan didapatkan hasil $\hat{P}=41,68+$ $0,27 X$, hal ini menunjukkan bahwa terdapat pengaruh yang positif antara tata ruang kantor (X) terhadap semangat kerja (Y) pada Kantor Pengawasan dan Pelayanan Bea dan Cukai Tipe Pratama Pematangsiantar.

d. Nilai korelasi yang diperoleh yaitu $r=0,44$ menunjukkan terdapat hubungan dalam kategori sedang antara variabel bebas yaitu (tata ruang kantor) terhadap variabel terikat yaitu (semangat kerja). Sedangkan untuk nilai koefisien determinasi $19,36 \%$ dapat dijelaskan oleh tata ruang kantor pada Kantor Pengawasan dan Pelayanan Bea dan Cukai Tipe Pratama Pematangsiantar, dan sisanya $(80,64 \%)$ dapat dijelaskan oleh faktor lain.

e. Hasil pengujian thit sebesar 2,59 sedangkan ttab 2,048 pada tingkat kepercayaan $95 \%$ dan $\alpha=$ $5 \%$. Oleh karena t hit 2,59>t tab 2,048, artinya tata ruang kantor berpengaruh positif terhadap semangat kerja pegawai, sehingga Ho ditolak dan Ha diterima.

\section{Saran}

a. Agar penerapan tata ruang kantor memiliki kontribusi yang lebih baik terhadap semangat kerja, diharapkan bagi Kantor Pengawasan dan Pelayanan Bea dan Cukai Tipe Pratama Pematangsiantar dapat memperhatikan efek efektivitas bukan hanya efek efesiensi saja, karena efesiensi tata ruang kantor belum tentu bisa membuat efektif suatu ruangan. Jadi apabila penataan tata ruang kantor dilakukan secara baik, maka meningkatkan kondisi arus kerja tata ruang kantor yang lebih baik, dengan memberikan peralatan kerja yang lebih baik, ruangan yang lebih bersih, fasilitas fisik, dan jaringan komunikasi agar para pegawai mampu mengoptimalkan pekerjaaannya dan betah dalam bekerja.

b. Agar terciptanya semangat kerja lebih optimal pada Kantor Pengawasan dan Pelayanan Bea dan Cukai Tipe Pratama Pematangsiantar, perusahaan perlu meningkatkan jalinan kekeluargaan sesama pegawai, seperti kegiatan arisan pegawai setiap bulannya dan family gathering setiap tahunnya. Apabila jalinan kekeluargaan sudah terhubung dan terjalin, maka secara tidak langsung akan memberikan efek peduli sesama pegawai, sehingga kerja sama antar pegawai di luar perusahaan maupun di dalam perusahaan akan lebih peduli dan terjalin secara optimal.

c. Sehubungan dengan keterbatasan-keterbatasan yang ada pada penulis, penelitian ini masih terdapat kelemahan-kelemahan dan belum dapat mengungkap seluruh variabel yang dapat meningkatkan semangat kerja pegawai pada Kantor Pengawasan dan Pelayanan Bea dan Cukai Tipe Pratama Pematangsiantar. Sebagai bahan masukan untuk penelitian selanjutnya, perlu memperbanyak variabel penelitian, seperti pemberian intensif, motivasi, dan kepemimpinan.

\section{E. DAFTAR PUSTAKA}

Gie, The Liang 2000, Administrasi Perkantoran Modern, Yogyakarta : Penerbit Liberty.

Hasibuan, Malayu S.P., 2004, Manajemen Sumber Daya manusia, Jakarta : Penerbit Gunung Agung.

Heidjarachman dan Suad, Husnan, 2000, Manajemen Personalia, Edisi ke 4, Yogyakarta : Penerbit BPFE. UGM.

Moekijat, 2002, Tata Laksana Kantor Cetakan Tujuh, Cetakan Tujuh, Bandung : Penerbit Mandar Maju.

Rivai, Viethzal, 2004, Manajemen Sumber Daya Manusia Untuk perusahaan, Jakarta : Penerbit Raja Grafindo.

Sedarmayanti, 2009, Dasar-Dasar Pengetahuan Tentang Manajemen Perkantoran, Bandung : Penerbit Mandar Maju.

Simamora, Henry, 2004, Manajemen Sumber Daya Manusia, Yogyakarta : Bagian penebit STIE YKPN.

Tohardi, Ahmad, 2002, Pemahaman Praktis Manajemen Sumber Daya Manusia. Pontianak : Penerbit Mandar Maju. 